\title{
BodiMojo: an internet-based body image promotion program
}

\author{
Debra Franko ${ }^{1 *}$, Rachel Rodgers ${ }^{1}$, Tara Cousineau ${ }^{2}$ \\ From 2013 ANZAED Conference: Inspiring Change: Person and Context \\ Melbourne, Australia. 23-24 August 2013
}

BodiMojo, an Internet program designed to promote positive body image in adolescents, was tested with 178 high school students (mean age 15.2 years, $67.6 \%$ ethnic minority) in 3 public high schools in the U.S. The BodiMojo group used the program for 4 class periods, while controls participated in their usual health curriculum. Body image measures were given at baseline, post-intervention, and 3-months. Girls reported decreased body dissatisfaction $(\mathrm{p}<.05)$, decreased physical appearance comparison $(\mathrm{p}<.05)$, and increased appearance satisfaction $(\mathrm{p}<.05)$, relative to controls. No effects were found for boys. Moderator analyses revealed a significant Group $\mathrm{x}$ Time $\mathrm{x}$ Overweight status interaction for body dissatisfaction among girls, with overweight girls reporting greater decreases in body dissatisfaction, $\mathrm{p}=.012$, partial $\eta 2=.15$. Among girls, there was a significant Group $\mathrm{x}$ Time $\mathrm{x}$ Ethnic minority status interaction for the Body Esteem Scale (Appearance subscale), $\mathrm{p}=.004$, partial $\eta 2=.14$, and body dissatisfaction, $\mathrm{p}=.029$, partial $\eta 2=.10$ with ethnic minority girls reporting greater increases in body appearance esteem than Caucasian girls. BodiMojo appears to be effective in decreasing body image concerns and appearance comparisons among adolescent girls and may be particular effective with some groups.

This abstract was presented in the Prevention stream of the 2013 ANZAED Conference.

\section{Authors' details}

${ }^{1}$ Northeastern University, USA. ${ }^{2}$ Cambridge Innovation Center, USA.

Published: 14 November 2013

* Correspondence: d.franko@neu.edu

'Northeastern University, USA

Full list of author information is available at the end of the article
doi:10.1186/2050-2974-1-S1-032

Cite this article as: Franko et al:: BodiMojo: an internet-based body image promotion program. Journal of Eating Disorders 2013 1(Suppl 1): O32.
Submit your next manuscript to BioMed Central and take full advantage of:

- Convenient online submission

- Thorough peer review

- No space constraints or color figure charges

- Immediate publication on acceptance

- Inclusion in PubMed, CAS, Scopus and Google Scholar

- Research which is freely available for redistribution
() Biomed Central

\section{Biomed Central}

